\title{
Migration in the COVID-19 Virus Era: New Challenges for Nursing
}

\author{
Theofanidis Dimitrios ${ }^{*}$ \\ MSC, PhD, Assistant Professor, Nursing Department, International Hellenic University, Thessaloniki, Greece \\ *Corresponding Author \\ Dr. Theofanidis Dimitrios
}

\section{Article History}

Received: 13.06 .2020

Accepted: 23.06 .2020

Published: 25.06.2020

\begin{abstract}
Greeks are often stereotyped as being socially disorganized, yet throughout their history have proven to be good at chaos management. The COVID-19 health and social crisis has emphasized the latter with Greece surpassing international expectations. Still, despite major difficulties mostly inflicted by a longstanding austerity, Greece now also needs to help and shield an overwhelming number of migrants and refugees currently residing in camps and elsewhere within the country. Despite the aggressive measures and lockdowns enforced at the beginning of the pandemic, Greek authorities are now moving towards lifting some of these controls. Yet, there is profound concern that there might be a sudden spike in some of the refugee camps, especially in the islands. Healthcare workers and nurses in particular have been portrayed as 'heroes of the day'. Yet, despite their heavy input and admirable response to tackle the corona virus emergency we still need to devote time to raise awareness of, and provide support for, the complex needs of our migrant populations.
\end{abstract}

Keywords: Greeksm, COVID-19, austerity, migrants.

\section{INTRODUCTION}

The current COVID-19 pandemic is a full-blown phenomenon; yet, it does not affect people, local communities and wider societies worldwide in the same manner. Renowned sociologists and economists warn that the poor countries of the Third World are at the bridge of plundering into chaos, which in effect will 'backfire' to world stability. Despite the fact that similar measures i.e. lockdown are taken by different governments the long-time effects are going to be so much different in Europe as opposed to Africa.

Therefore, we should be expecting that the process of further deprivation, of the ones already in deep austerity, will end up in a 'tsunami' of global proportions of migration to more affluent states. Another challenging parameter of the global fight against COVID-19, is the difficulty of imposing and safeguarding measures in countries with poor socioeconomic fabric. Overcrowding and lack of public sanitary infrastructure in places with dense population, such as slums alongside capitals in many countries in Asia, South America or Africa, is an uncomfortable reality that the world has to face during and after the pandemic.

The poorest countries, due to the very fact that they have been deprived and disadvantaged for decades, do not have the necessary mechanisms and tools to both adequately inform and protect their citizens. Thus, people who do not have the necessary educational background and discipline may divert to violence. In this case, the government's mechanisms for enforcing social order will be seriously challenged.

Another, huge issue with unpredictable side effects is internal migration. In large countries such as India, China or Mongolia (where half of the country's population lives in the capital) where there is a well-known urbanization for reasons of economic survival, a reverse social phenomenon is observed due to the epidemic, whereby city dwellers are heading back to the countryside. In this way, however, the risk of spreading the corona virus may be multiplied.

Copyright @ 2020: This is an open-access article distributed under the terms of the Creative Commons Attribution license which permits unrestricted use, distribution, and reproduction in any medium for non commercial use (NonCommercial, or CC-BY-NC) provided the original author and source are credited. 
Moreover, it is self-evident for the poorest countries on the planet, that their 'shadow economies' will suffer the most. Those who make a living as peddlers, doing virtually any job just for basic living, are doomed to starvation in lockdown conditions.

\section{COVID-19 Affecting Immigrant Services}

Although not in many cases anticipated, Greece has been globally widely perceived as a model paradigm during the first wave of the COVID crisis. Currently in Greece (June 2020) the quarantine for COVID-19 has been lifted, yet measures for public health and safety are still in place with the use of a facial mask being obligatory on public transport and special rules also applying for dining out. With Greece having a relatively low incidence and death rate due to COVID-19 (especially when compared to other Mediterranean countries) concern is still mounting over its migrant population.

Although all asylum applications were suspended in March 2020, these are now gradually being lifted and interviews and appeal submissions are being considered. There was a brief temporary extension for those with applicants' cards and residence permits that were due during the initial lockdown period and these remained valid. Although currently, immigrants and refugees can apply for services online, the majority still prefers to wait in long queues outside the immigration offices with the appropriate social distancing measures not being reinforced due to the overwhelming number of applicants, a relevant inability to reinforce law and order (by Greek authorities) coupled with an eager effort to be 'the first in line' (by the immigrants).

Services at Greek island migrant camps were also placed in lockdown in March 2020, with classes for migrant children suspended. Yet, as of April 2020, the five Aegean islands hotspots experienced excessive overcrowding, with inadequate sanitation and limited access to healthcare services. Under these circumstances, the risk of COVID-19 spread was considerably increased [1]. The Greek government reinforced isolation precaution measures, in an attempt to lessen the burden of life in the camps. This entailed restrictive measures for resident movements whereby only one person per family or group could leave the hotspot within a stipulated period of time, and only for reasons related to basic needs.

\section{Reflection}

As a nurse, from a personal viewpoint, I witnessed considerable suffering in a refugee camp situated in the outskirts of Thessaloniki (second capital of Greece) where people from various nations and backgrounds were trying to survive adverse conditions. Another more recent relevant experience I had occurred while doing volunteer work with refugees at the northern Greek border I had been assessing health care needs with a group of nurses and other health care professionals. Apart basic help offered, i.e. food preparation and essential health care, I was initially shocked to find out that my services were needed in more complex situations where by my training, personal preparation and experience were proven totally inadequate.

To illustrate this situation, here is a relevant example. I had been serving food on a daily basis to long queues of migrants and over time I noticed a particular family of a woman with four children who were systematically hiding food under their garments. Why confronted them that they can have as much food they needed without having to 'save', I found out that they have been delivering food to their dad in the tent. When asked why he doesn't come along as well, I was told he was sick. As a health care professional I visited the tent in order to assess his health status. This was a tiny tent to sleep 3-4 people and yet on entering I could not see him inside. Being baffled about the whole situation, I was told by the family that 'he is there'. To my amazement, this small figure of a person, particularly frail, rose from a dark corner, as if he unearthed, like a frightened bird, and started screaming wanting no interaction at all. The wife explained that during the war, he had alienated from the family due to severe trauma. He had lost all communication abilities including that of speech. His needs were so great that referral to a specialist was imperative, despite the family's reluctance to receive help for him as their goal was to move on further north with him undetected. Yet, various studies have shown that post-traumatic stress disorder is prevalent amongst migrants groups, especially those fleeing war zones [2-4].

\section{Conclusions}

As a nurse, I find it quite challenging to create ways of raising public awareness within our profession and the wider public too on the precarious state that many migrants are suffering and how this should be tackled. During the COVID-19 era, nurses (amongst other healthcare professionals) have been portrayed as modern time 'heroes' especially those in the frontline of healthcare delivery. Yet, in my view, true heroism entails being a solid professional but still find the time to think and care for those under 'the grid', the underprivileged i.e. the ones who have not just limited access to healthcare but restricted information on the scope of the social, economic and health catastrophe that COVID-19 is forcing upon communities and societies. 


\section{REFERENCES}

1. Médecins Sans Frontières, COVID-19: Evacuation of squalid Greek camps more urgent than ever in light of coronavirus pandemic, 13 March 2020.

2. Wrobel, N., Farrag, M., \& Hymes, R. Acculturative stress and depression in an elderly Arabic sample. Journal of Cross-Cultural Gerontology. 2009;24(3):273-290

3. Kira, I., \& Wrobel, N. (2016). Trauma: Stress, coping, and emerging treatment models. In Amer, M. M., \& Awad, G. H. (Eds.), Handbook of Arab American psychology, 188-205.

4. Theofanidis, D., \& Fountouki, A. (2019). Nursing and Contemporary Migration in Greece. International Journal of Caring Sciences, 12(2):1237-1243. 